\title{
Higher Returns through Intercropping and Mulching in Irrigated Finger Millet Cultivation
}

\author{
R. Vishalini ${ }^{1}$, D. Rajakumar ${ }^{1 *}$, M. Joseph ${ }^{1}$ and M. Gomathy ${ }^{2}$ \\ ${ }^{1}$ Department of Agronomy, ${ }^{2}$ Department of SS \& AC, Agricultural College and Research \\ Institute, Killikulam, Vallanadu 628 252, Tamil Nadu, India \\ *Corresponding author
}

\section{A B S T R A C T}

\section{Keywords}

Irrigated Finger Millet Cultivation, Mulching

Article Info

Accepted:

24 August 2020

Available Online:

10 September 2020
An experiment was conducted at Department of Agronomy, Agricultural College and Research Institute, Killikulam to achieve enhanced remuneration and profit margin in irrigated finger millet through intercropping and mulching. Among mulching, the highest gross return (Rs.68,336/- ha ${ }^{-1}$ ) and $\mathrm{B}: \mathrm{C}$ ratio of 2.16 was obtained in rice straw mulch $\left(\mathrm{M}_{1}\right)$ which was followed by $\mathrm{M}_{2}$ (shredded coconut waste mulch) with a gross return of Rs.63,635/- ha $^{-1}$ and B:C ratio of 2.01. Similar trend in net return was observed because of higher crop yield. The lowest B:C ratio of 1.69 was realized under un-mulched. Among the intercropping, the highest gross return (Rs.1,08,255/- ha ${ }^{-1}$ ) was fetched in small onion intercrop followed by $\mathrm{I}_{4}$ (palak intercrop). The highest $\mathrm{B}: \mathrm{C}$ ratio of 2.66 was obtained in small onion intercrop which was followed by palak intercrop. The combination of rice straw mulch with small onion intercrop recorded the highest gross and net returns of Rs.1,21,178/- and Rs.80,489/- respectively with B:C ratio of 2.98. The same intercrop with shredded coconut mulch was also proved to be the next best combination. Unmulched non intercropped treatment $\left(\mathrm{M}_{0} \mathrm{I}_{0}\right)$ registered the lowest $\mathrm{B}: \mathrm{C}$ of 1.22 followed by shredded coconut waste mulch $\left(\mathrm{M}_{2} \mathrm{I}_{0}\right)(1.25)$ due to lower productivity.

\section{Introduction}

In the recent past, this nutraceutical crop is demanding an increasing recognition owing to their favourable nutrient composition and utility as health food. Thus, their traditional role as a staple of the poor in the marginal agricultural regions is transforming and revolutionizing to a new role as crop of healthy food for the urban high income people. Though, finger millet possesses tremendous potential for product diversification, lack of remunerative price to cover the cost of cultivation and reasonable profit margin become cause of concern to grow finger millet by farmers. Lower yield combined with lower price leading to reduced returns is one of the main reasons for decreased area under finger millet cultivation. Thus, a decline in area under finger millet at a rate of -2.6 per cent during the period from $1984-85$ to $2013-14$ has been noticed which is attributed to increased cost of cultivation and reduced returns (Sakamma et al., 2018). In 
such a situation, organic farming in finger millet cultivation can be introduced as a mean to provide a premium price to the growers that has tremendous scope and potential as food in domestic and world market. As an eco-friendly crop, finger millet is suitable for organic agriculture as compared to many other cereals. It is evident that rather than nutrient management, weed management in finger millet is crucial and vital in increasing the crop yield. With the above in view, and to address non chemical weed management issues and experiment was conducted to achieve enhanced remuneration and profit margin of finger millet through intercropping and mulching.

\section{Materials and Methods}

Field experiment was conducted at the 'B' block Farm of Department of Agronomy, Agricultural College and Research Institute, Killikulam. The soil of the experimental field is sandy clay loam in texture, neutral in reaction and low, medium and medium in available $\mathrm{N}, \mathrm{P}$ and $\mathrm{K}$ content respectively. Finger millet variety $\mathrm{CO}-15$ was used as test crop in this experiment. The experiment was laid out in a Factorial Randomized Block Design (FRBD) with two factors and replicated thrice. Rice straw and shredded coconut wastes (10 tonnes $\mathrm{ha}^{-1}$ ) used as mulches in the experiment were the main factors. Black gram (Vigna mungo L.), Coriander (Coriandrum sativam L.), Small onion (Allium cepa L.) and Palak (Spinacia oleracea L.) used as intercrops were the sub factors. Intercrops were sown at 1:1 proportion in additive series and sown on the same day as of finger millet.

The economics was worked out for all the treatment combinations. The cost of inputs, labour charges and prevailing market rates of farm produce were taken into consideration for working out the economics. Cost benefit analysis was worked out for all the treatments using the following formula.

Net retum (Net retum $\left.₹ h^{-1}\right)=\operatorname{Gross}$ retum $\left(₹ h^{-1}\right)-\operatorname{Cost}$ of cultivation $\left(₹ h^{-1}\right)$
Cost $:$ Benefit ratio $=\frac{\text { Gross return }\left(₹ \mathrm{ha}^{-1}\right)}{\text { Cost of cultivation }\left(₹ \mathrm{ha}^{-1}\right)}$

\section{Results and Discussion}

In socio economic view point, amongst the causes for crisis in finger millet, high cost of cultivation in the absence of family labours and the lowest market price it deserves are the prime concern. This causes seclusion of millet growers from others who have been traditionally depending on this crop for their food security and income. The cost of cultivation attributed to cost of seed, fertilizer, land preparation and cultural operations as per the treatments. Fixed costs were not included to estimate the cost of cultivation. With respect to cost of mulching, since the unutilized farm waste materials that were neither suitable either for feeding cattle nor fit for further value addition were used, the cost of shredding and application were alone considered. The total cost of production was found to be Rs.23,792/- without intercropping and it was highest in onion intercropped fields (Rs.40,689/-) and this was due to the high cost involved in seed bulb of aggregatum onion. Generally, all the intercropped fields registered higher total cost of cultivation which was due to the labourers engaged in sowing of intercrops and harvesting them and always conceded while accruing the multiple benefits of intercropping. But, engaging family labours could bring down the cost involved in intercropping and harvesting charges.

Returns from organic mulching and intercropping systems of finger millet revealed that all the intercropping systems were found to give additional remuneration than the sole crop (Table 1). 
Table.1 Effect of organic mulching and intercropping on returns and benefit cost ratio of irrigated finger millet

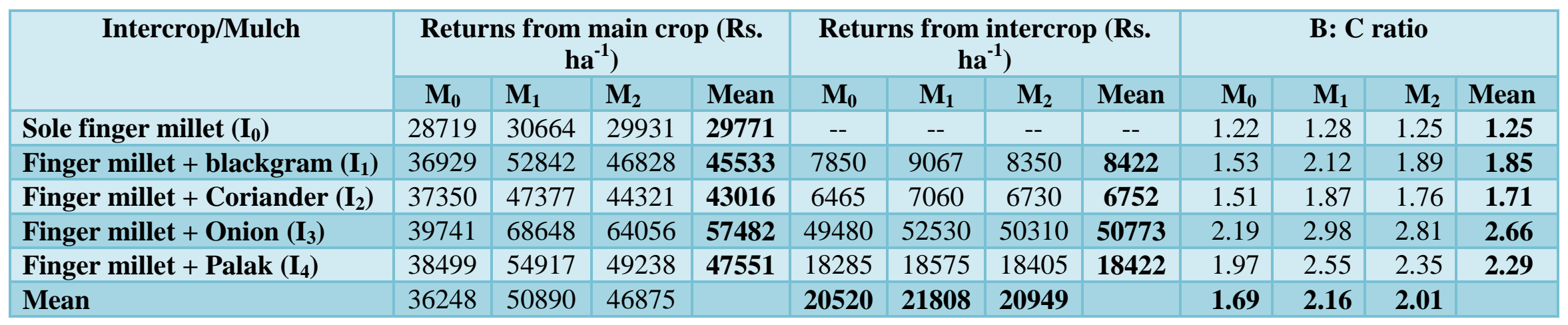

Fig.1 Organic mulches and intercropping on economics of irrigated finger millet

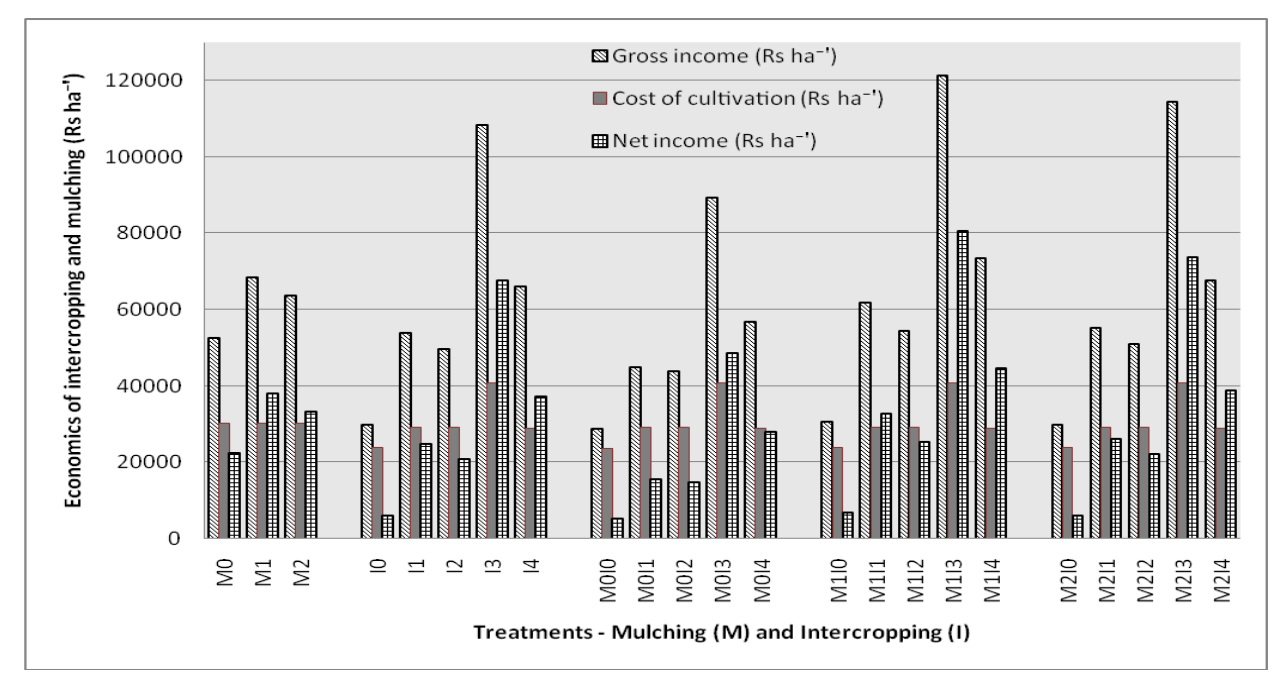


Though coriander and palak were sold as greens, palak fetched more profit with its ability of regrowth and repeated harvests (Rs.18,422/- as against Rs.6,752/-). Coriander was also found to have low germination per cent. Similarly, mulching with either rice straw or coconut shredded waste gave added returns than non-mulched finger millet due to efficient management of weeds during the early stages of crop growth. The highest return was recorded in onion intercropping system which was not only attributed to the higher productivity but also to higher sale price of aggregatum onion which is a high remunerative crop in India.

Among the mulching treatments, the highest gross return ( $₹$ 68,336/- ha $^{-1}$ ) was obtained in rice straw mulch $\left(\mathrm{M}_{1}\right)$ which was followed by $\mathrm{M}_{2}$ (shredded coconut waste mulch) ( ₹ 63,635/- $\mathrm{ha}^{-1}$ ). This was mainly due to higher yield obtained in these treatments. Similar trend in net return was observed owing to higher crop yield. Among the mulches, highest B:C ratio of 2.16 was obtained in rice straw mulch which was closely followed by shredded coconut waste mulch (2.01). Lower cost of cultivation and higher returns could have contributed for higher $\mathrm{B}: \mathrm{C}$ ratio in the above treatments. The lowest B:C ratio of 1.69 was noted under unmulched. Similar finding was given by Ehsanullah et al., (2014) in direct sown rice. Karunakaran and Behera (2013) reported higher net return and benefit cost ratio in pearl millet with green leaf manure and maize residue mulch.

Among the intercropping, the highest gross return ( ₹ 1,08,255/- ha ${ }^{-1}$ ) was fetched in small onion intercrop due to higher returns of the produce both from main as well as intercrop followed by $\mathrm{I}_{4}$ (palak intercrop). Same trend was observed with regard to net return also ( $₹ 67,566 /-\mathrm{ha}^{-1}$ in small onion and $₹ 37,186 /-$ ha $^{-1}$ in palak intercrop) owing to higher returns (Fig. 1). The highest B:C ratio of 2.66 was obtained in small onion intercrop which was followed by palak intercrop (2.29). Similar finding was observed by Sharmili and Manoharan (2018) who concluded that intercropping of little millet with small onion registered higher net return and $\mathrm{B}: \mathrm{C}$ ratio.

The combination of rice straw mulch with small onion intercrop recorded the highest gross and net returns of ₹ 1,21,178/- and ₹ 80,489/- respectively with B:C ratio of 2.98 in spite of high seed bulb input cost. The same intercrop with shredded coconut mulch was proved to be the next best combination with gross return of ₹ 1,14,366/-, net return of ₹ 73,677/- and B:C ratio of 2.81. Unmulched non intercropped treatment $\left(\mathrm{M}_{0} \mathrm{I}_{0}\right)$ registered the lowest $\mathrm{B}: \mathrm{C}$ ratio of 1.22 followed by shredded coconut mulch without intercrop $\left(\mathrm{M}_{2} \mathrm{I}_{0}\right)$ (1.25) due to lower productivity.

In conclusion the application of rice straw mulching on 3 DAS and intercropping small onion $(1: 1)$ was found to be effective in managing weeds in irrigated finger millet with higher net returns ( ₹ 80,489/- ha ${ }^{-1}$ ) and $\mathrm{B}: \mathrm{C}$ ratio (2.98). If rice straw is not accessible, shredded coconut waste mulch could be used for mulching as a tool for organic weed management with small onion intercropping.

\section{References}

Sakamma, S, KB Umesh, MR Girish, SC Ravi, M Satishkumar, and Veerabhadrappa Bellundagi. 2018. Finger millet (Eleusine coracana L. Gaertn.) production system: status, potential, constraints and implications for improving small farmer's welfare. J. Agric. Sci.10:162- 179.

Sharmili, K, and S. Manoharan. 2018. Studies 
on Intercropping in Rainfed Little Millet (Panicum sumatrense).Int. J. of Current Microbiology and Applied Sci., 7(2): 323-327.

Ehsanullah, R. Qamar, M. K. Abdul Rehman, Z. Iqbal, A. Ghaffar and G. Mustafa. 2014. Growth and economic assessment of mulches in aerobic rice (Oryza sativa L.). J. Agric. Res., 2014, 52 (3):
Karunakaran, V. and Behera, U. K. 2013. Effect of tillage management \& crop establishment techniques on energetics, water use efficiency \& economics in soybean (Glycine max) - wheat (Triticum aestivum) cropping system. Indian J. Agron. 58(1): 42-47.

\section{How to cite this article:}

Vishalini, R., D. Rajakumar, M. Joseph and Gomathy, M. 2020. Higher Returns through Intercropping and Mulching in Irrigated Finger Millet Cultivation. Int.J.Curr.Microbiol.App.Sci. 9(09): 3399-3403. doi: https://doi.org/10.20546/ijcmas.2020.909.422 